\title{
Pengaruh Devidend Payout Ratio, Devidend Yield, Ukuran Perusahaan, Volume Perdagangan, Nilai Tukar, Inflasi, dan Tingkat Suku Bunga Terhadap Volatilitas Harga Saham Pada Perusahaan Manufaktur Yang Tercatat Di Bursa Efek Indonesia Tahun 2012-2016
}

\author{
Syarifah Nur Azura, Myrna Sofia, Nurhasanah, Firmansyah Kusasi
}

Fakultas Ekonomi Universitas Maritim Raja Ali Haji, Tanjungpinang, Kepulauan Riau, Indonesia

\begin{abstract}
ABSTRAK: Penelitian ini bertujuan untuk melihat pengaruh Devidend Payout Ratio, Devidend Yield, Ukuran perusahaan, Volume Perdagangan, Nilai Tukar, Inflasi, Tingkat Suku Bunga Terhadap Volatilitas Harga Saham. Dengan teknik pengambilan sampel purposive sampling, penelitian ini mengambil 7 perusahaan sebagai sampel dari 153 perusahaan Manufaktur yang terdaftar di Bursa Efek Indonesia tahun 2012-2016. Analisis data dilakukan dengan menggunakan Regresi Berganda. Hasil penelitian menunjukkan bahwa Devidend Payout Ratio mempunyai pengeruh terhadap Volatilitas Harga Saham, sedangkan Devidend Yield, Ukuran perusahaan, Volume Perdagangan, Nilai Tukar, Inflasi dan Tingkat Suku Bunga tidak berpengaruh terhadap Volatilitas Harga Saham. Sementara secara simultan keseluruh variable bebas yang diuji menunjukkan pengaruh signifikan terhadap Volatilitas Harga Saham pada perusahaan Manufaktur yang terdaftar di Bursa Efek Indonesia tahun 2012-2016.
\end{abstract}

Kata kunci : Devidend Payout Ratio, Devidend Yield, Ukuran perusahaan, Volume Perdagangan, NilaI Tukar, Inflasi, Tingkat Suku Bunga ,Volatilitas Harga Saham

ABSTRACT: The aims of this study is to look at the effect of Devidend Payout Ratio, Devidend Yield, Company Size, Trading Volume, Exchange Rate, Inflation, Interest Rate Against Stock Price Volatility. With a purposive sampling technique, this study took 7 companies as samples of 153 manufacturing companies listed on the Indonesia Stock Exchange in 2012-2016. Data analysis was performed using Multiple Regression. The results of the study show that the Devidend Payout Ratio has an effect on Stock Price Volatility, while the Devidend Yield, Company Size, Trading Volume, Exchange Rate, Inflation and Interest Rate do not affect the Stock Price Volatility. While simultaneously all the independent variables tested showed a significant effect on Stock Price Volatility in Manufacturing companies listed on the Indonesia Stock Exchange in 2012-2016.

Key words: Devidend Payout Ratio, Devidend Yield, Size, Trading Volume, Exchange Rate, Inflation, Rate Interest, Share Price Volatility.

Email Address : s.nurazura@gmail.com 


\section{PENDAHULUAN}

\section{Latar Belakang Masalah}

Pasar modal merupakan sarana pendanaan bagi perusahaan maupun istitusi lain (misalnya pemerintah) dan sarana bagi kegiatan berinvestasi. Dengan demikian pasar modal memfasilitasi berbagai sarana dan prasarana kegiatan jual beli dan kegiatan terkait lainnya. Pasar modal memiliki peran strategis bagi penguatan ketahanan ekonomi suatu negara.

Saham merupakan nilai sekarang dari arus kas yang akan diterima oleh pemilik saham dikemudian hari. Persentase kepemilikan ditentukan oleh besarnya persentase jumlah saham terhadap keseluruhan saham perusahaan. Seseorang yang memiliki saham suatu perusahaan dapat dikatakan sebagai pemilik perusahaan walaupun jumlah sahamnya hanya beberapa lembar.

Volatilitas harga saham adalah pergerakan naik turunnya harga saham di dalam bursa efek (Khumiaji dan Raharja 2013 ). Volatilitas adalah pengukuran statistik untuk fluktuasi harga selama periode tertentu. Pengaruh volatilitas harga saham kita bisa melihat dan mengukur dengan aspek aspek tertentu antara lain yaitu devidend payout ratio, devidend yield, nilai tukar, inflasi, ukuran perusahaan, tingkat suku bunga, volume perdagangan.

Deviden Payout Ratio merupakan persentase laba perusahaan yang dibagikan kepada para pemegang saham atau investor terhadap total laba perusahaaan. Dividend yield adalah suatu cara untuk menentukan seberapa besar suatu perusahaan dalam membagikan dividend kepada pemilik saham dilihat dari harga sahamnya yang sekarang. Nilai tukar rupiah adalah harga rupiah terhadap mata uang negara lain Inflasi ialah suatu proses dari suatu kenaikan harga pada umumnya dan akan bergerak secara terus-menerus Ukuran perusahaan adalah suatu skala atau nilai dimana perusahaan dapat diklasifikasikan besar kecilnya berdasarkan total aktiva, log size, nilai saham dan lain sebagainya. Volume perdagangan saham adalah banyaknya lembaran saham suatu emiten yang diperjualbelikan di pasar modal setiap hari dengan tingkat harga yang disepakati oleh pihak penjual dan pembeli saham.

Penelitian Hugida dan Sofian (2011) dengan judul jurnalnya Analisis Faktor $\neg$ Faktor yang mempengaruhi Volatilitas Harga Saham mendaptkan hasilpenelitian yaitu volume perdagangan, inflasi, dan tingkat suku bunga berpengaruh positif terhadap volatilitas harga saham, dan nilai tukar, suku bunga, berpengaruh negatif terhadap volatilitas harga saham. Sedangkan berdasarkan penelitian Rahmawati (2017) dengan judul jurnal pengaruh volume perdagangan, devidend payout ratio, inflasi terhadap volatlilitasharga saham pada perusahaan yang terdaftar dalam indeks LQ45 tahun 2011-2015 mendapatkan hasil penelitian yaitu volume perdagangan, devidend payout ratio, berpengaruh terhadap vlatilitas harga saham, dan inflasi tidak berpengaruh terhadap volatilitas harga saham. Berdasarkan jurnal internasional penelitian yang dilakukan oleh Hashemijoo et all (2012) dengan judul jurnal The Impact of Dividend Policy on Share Price Volatility in the Malaysian Stock Market mendapatkan hasil bahwa Devidend Payout Ratio berpengaruh secara signifikan, sedangkan penelitian yang dilakukan oleh Kenyoru et all(2013) dengan judul jurnal Devidend Policy and Share Price Volatility in Kenya mendapatkan hasil bahwa Devidend Payout Ratio berpengaruh secara signifikan tetapi Devidend Yield tidak berpengaruh secara signifikan.

Berdasarkan kejadian yang terjadi, maka peneliti ingin dan termotivasi untuk melakukan pengujian kembali untuk mengetahui faktorfaktor apa saja yang mepengaruhi Volatilitas Harga Saham terutama dengan Objeknya Perusahaan Manufaktur dengan mengembangkan penelitian-penelitian terdahulu.

\section{Rumusan Masalah}

Berdasarkan latar belakang dan judul penelitian, maka rumusan masalah yang dapat dikemukakan dalam penelitian ini adalah : 
1. Apakah devidend payout ratio berpengaruh terhadap volatilitas harga saham pada Perusahaan Manufaktur yang Tercatat pada Bursa Efek Indonesia Tahun 2012-2016?

2. Apakah devidend yield berpengaruh terhadap volatilitas harga saham pada Perusahaan Manufaktur yang Tercatat pada Bursa Efek Indonesia Tahun 20122016 ?

3. Apakah ukuran perusahaan berpengaruh terhadap volatilitas harga saham pada Perusahaan Manufaktur yang Tercatat pada Bursa Efek Indonesia Tahun 20122016 ?

4. Apakah volume perdagangan berpengaruh terhadap volatilitas harga saham pada Perusahaan Manufaktur yang Tercatat pada Bursa Efek Indonesia Tahun 20122016 ?

5. Apakah nilai tukar berpengaruh terhadap volatilitas harga saham pada Perusahaan Manufaktur yang Tercatat pada Bursa Efek Indonesia Tahun 2012- 2016 ?

6. Apakah inflasi berpengaruh terhadap volatilitas harga saham pada Perusahaan Manufaktur yang Tercatat pada Bursa Efek Indonesia Tahun 2012-2016?

7. Apakah tingkat suku bunga berpengaruh terhadap volatilitas harga saham pada Perusahaan Manufaktur yang Tercatat pada Bursa Efek Indonesia Tahun 20122016 ?

8. Apakah Devidend Payout Ratio, Devidend Yield, Nilai Tukar, Inflasi, Ukuran Perusahaan, Tingkat Suku Bunga, Volume Perdagangan berpengaruh terhadap volatilitas harga saham pada Perusahaan Manufaktur yang Tercatat pada Bursa Efek Indonesia Tahun 20122016 ?

\section{Kajian Teori}

Volatilitas harga saham adalah pergerakan naik turunnya harga saham di dalam bursa efek
- Deviden Payout Ratio merupakan persentase laba perusahaan yang

dibagikan kepada para pemegang saham atau investor terhadap total laba perusahaaan Dividend yield adalah suatu cara untuk menentukan seberapa besar suatu perusahaan dalam membagikan dividend kepada pemilik saham dilihat dari harga sahamnya yang sekarang.

- Ukuran perusahaan adalah suatu skala atau nilai dimana perusahaan dapat diklasifikasikan besar kecilnya berdasarkan total aktiva, log size, nilai saham dan lain sebagainya.

- Volume perdagangan saham adalah jumlah lembar saham yang diperdagangkan pada periode tertentu.

- Nilai tukar rupiah adalah harga rupiah terhadap mata uang negara lain

- Inflasi ialah suatu proses dari suatu kenaikan harga pada umumnya dan akan bergerak secara terus-menerus

Untuk kasus Indonesia, tingkat suku bunga Bank sentral di proxykan pada tingkat suku bunga Sertifikat Bank Indonesia atau SBI (Husnan, 2000).

\section{Populasi dan Sampel}

Populasi adalah wilayah generalisasi yang terdiri atas: obyek/subyek yang mempunyai kualitas dan karakteristik tertentu yang ditetapkan oleh peneliti untuk dipelajari dan kemudian ditarik kesimpulannya (Sugiyono, 2016:80). Populasi dalam penelitian ini adalah seluruh perusahaan manufaktur yang terdaftar di Bursa Efek Indonesia selama 5 periode yaitu tahun 2012, 2013, 2014, 2015, dan 2016 yang bejumlah 153 perusahaan.

Sedangkan sampel merupakan bagian dari jumlah dan karakteristik yang dimiliki oleh

populasi (Sugiyono, 2016:81). Dalam penelitian ini jumlah sampel yang digunakan ditentukan dengan menggunakan teknik Purposive Sampling yaitu penentuan sampel 
berdasarkan kriteria-kriteria tertentu dan menurut Sugiyono (2016:85) Purposive Sampling adalah teknik penentuan sampel dengan pertimbangan tertentu, maka didapatilah 7 perusahaan yang akan menjadi sampel, dengan kode IDXnya sebagai berikut: TOTO, ASII, AUTO, BATA, MLBI, SMSM, dan UNVR.

Uji Regresi Berganda
Teknik analisis yang digunakan untuk melakukan pengujian hipotesis dalam penelitian ini adalah analisis regresi berganda. Analisis regresi berganda ini digunakan untuk mengetahui apakah Devidend Payout Ratio, Devidend Yield, Ukuran Perusahaan, Volume Perdagangan, Nilai Tukar, Inflasi, Tingkat Suku Bunga memiliki pengaruh atau tidak terhadap volatilitas harga saham.

Tabel 1. Hasil Uji Analisis Regresi Linier Berganda

\begin{tabular}{|c|c|c|c|c|}
\hline \multirow{2}{*}{ Model } & \multicolumn{2}{|c|}{ Unstandardized Coefficients } & \multirow{2}{*}{$\begin{array}{c}\text { Standardized } \\
\text { Confficiontc } \\
\text { Beta }\end{array}$} & \multirow{2}{*}{$\mathbf{t}$} \\
\hline & B & Std. Error & & \\
\hline (Constant) & ,022 &, 078 & & ,289 \\
\hline DPR & ,079 & ,037 & ,474 & 2,106 \\
\hline DY &, 234 & ,906 & ,053 & 259 \\
\hline UP &,- 012 & ,007 &,- 268 & $-1,638$ \\
\hline VP & ,621 & ,629 &, 158 & ,988 \\
\hline NT & ,042 & ,096 & ,135 & ,440 \\
\hline INF & ,078 &, 525 & ,036 &, 148 \\
\hline TSB & 1,671 & 1,594 & ,275 & 1,048 \\
\hline
\end{tabular}

Dependent Variable: VHS

Tabel 1. diatas menunjukkan hasil uji regresi berganda yang diperoleh setelah data outlier dihilangkan, maka diperoleh persamaan regresi sebagai berikut :

$\mathrm{Y}=0.022 \alpha+0.079 \mathrm{DPR}+0.234 \mathrm{DY}-0.012 \mathrm{UP}+0.621 \mathrm{VP}+0.042 \mathrm{NT}+0.078 \mathrm{INF}+1.671$ TSB

Dari persamaan diatas diketahui konstanta sebesar 0.022 menyatakan bahwa Devidend Payout Ratio, Devidend Yield, Ukuran Perusahaan, Volume Perdagangan, Nilai Tukar, Inflasi, dan Tingkat Suku Bunga bernilai 0 (nol), maka nilai Volatilitas Harga Saham sebesar 0.022 .

Tabel 1. juga memperlihatkan hasil Uji tstatistik pada kolom terakhir paling kanan. Uji ini pada dasarnya menunjukkan seberapa jauh pengaruh satu variabel penjelas atau independen secara individual dalam menerangkan variasi variabel dependen. Pengambilan keputusan uji $\mathrm{t}$ adalah jika $\mathrm{t}$ hitung > t tabel maka $\mathrm{H} 0$ di tolak dan $\mathrm{H} 1$ diterima dan jika $\mathrm{t}$ hitung $<\mathrm{t}$ tabel maka Ho diterima dan $\mathrm{H} 1$ ditolak

(Ghozali, 2011).

Sedangkan secara keseluruhan atau simultan, semua variabel bebas memberikan pengaruh yang signifikan. Ini dapat dilihat berdasarkan hasil analisis uji $\mathrm{F}$ yang

diperlihatkan pada Tabel 2. Dapat dilihat bahwa secara simultan variabel indepnden memiliki nilai signifikan $0.032<0.050$ dan Fhitung 2.713. nilai Ftabel df1(k-1) $=7$ dan 
df2 (n-k) = 23 yaitu 2.42. Maka dapat disimpulkan bahwa Fhitung2.713 > 2.42 Ftabel

sehingga $\mathrm{H} 0$ ditolak dan $\mathrm{H} 1$ diterima dengan arti bahwa secara simultan variabel independen berpengaruh terhadap volatilitas harga saham.

\section{Tabel 2. Hasil Uji F}

\begin{tabular}{|cc|c|c|c|l|}
\hline & Model & Sum & Mean & F & Sig. \\
\hline 1 & Regres &, 037 &, 005 & 2,713 &, $032^{\mathrm{b}}$ \\
& Residual &, 047 &, 002 & & \\
& & & \\
\hline & Total & & & & \\
\hline
\end{tabular}

a. Dependent Variable: VHS

b. Predictors: (Constant), TSB, VP, INF, UP, DY, DPR, NT

\section{Pembahasan}

\section{Pengujian Hipotesis Pertama}

Ha1: Devidend Payout Ratio berpengaruh signifikan terhadap volatilitas harga saham.

Berdasarkan pada tabel 4.7 hasil uji regresi linier berganda diperoleh nilai signifikansi $(0.46<0.05)$. Sedangkan nilai Thitung $2.106>$ Ttabel 2.06 menunjukkan bahwa variabel devidend payout ratio berpengaruh secara positif dan signifikan terhadap volatilitas harga saham pada perusahaan manufaktur yang terdaftar di Bursa Efek Indonesia periode 2012-2016, sehingga hipotesis pertama diterima. Hasil penelitian ini sesuai dengan penelitian yang dilakukan oleh Anastassia \& Firnanti (2014) serta penelitian yang dilakukan oleh Rahmawati(2017), hasil penelitian tersebut menunjukkan bahwa devidend payout ratio mempunyai pengaruh terhadap volatiltas harga saham. Akan tetapi berbeda dengan hasil penelitian yang dilakukan oleh Khurniaji(2013) yang menyatakan bahwa devidend payout ratio tidak berpengaruh secara signifikan terhadap

volatiltas harga saham. Perbedaan hasil penelitian ini bisa disebabkan karena perbedaan sampel yang digunakan serta periode yang digunakan.
Deviden Payout Ratio merupakan persentase laba perusahaan yang dibagikan kepada para pemegang saham atau investor

terhadap total laba perusahaaan. Dengan meningkatnya kemampuan perusahaan menghasilkan laba yang juga diiringi dengan semakin besarnya dividen yang dibagikan maka akan menyebabkan peningkatan harga saham. Hal ini dikarenakan banyak investor yang tertarik untuk membeli saham perusahaan yang memiliki kemampuan yang tinggi dalam menghasilkan laba, sehingga permintaan akan saham tersebut meningkat.

\section{Pengujian Hipotesis Kedua}

$\mathrm{Ha} 2$ : Devidend Yield berpengaruh signifikan terhadap volatilitas harga saham

Berdasarkan pada tabel 4.7 hasil uji regresi linier berganda diperoleh nilai signifikansi $(0.798>0.05)$, ). Sedangkan nilai Thitung $0.259<$ Ttabel 2.06 menunjukkan bahwa variabel deviden yield tidak berpengaruh signifikan terhadap volatilitas harga saham pada perusahaan manufaktur yang terdaftar di Bursa Efek Indonesia periode 2012-2016, sehingga hipotesis kedua ditolak. Hasil penelitian ini sesuai dengan penelitian yang dilakukan oleh Khurniaji (2013) yang menyatakan bahwa devidend yield tidak berpengaruh terhadap volatilitas harga saham. Akan tetapi berbeda dengan hasil penelitian yang dilakukan oleh Anastassia \& Firnanti(2014) yang menyatakan bahwa devidend yield memiliki pengaruh yang signifikan terhadap volatilitas harga saham. Perbedaan hasil penelitian ini bisa disebabkan karena perbedaan sampel yang digunakan serta periode yang digunakan.

Dividend yield adalah suatu cara untuk menentukan seberapa besar suatu perusahaan dalam membagikan dividend kepada pemilik

saham dilihat dari harga sahamnya yang sekarang. Dalam analisa fundamental dividen yield juga merupakan salah satu faktor untuk menentukan imbal hasil dari suatu saham. 
Secara sederhana semua investor pasti menginginkan dividend yield yang besar namun dividen yield yang besar memiliki dampak negatif seperti pengurangan modal,

dan pengurangan modal dapat berdampak pada turunnya produktivitas perusahaan.

\section{Pengujian Hipotesis Ketiga}

Ha3 : Ukuran Perusahaan berpengaruh signifikan terhadap volatilitas harga saham

Berdasarkan pada tabel 4.7 hasil uji regresi linier berganda diperoleh nilai signifikansi $(0.114>0.05)$. Sedangkan nilai Thitung $-1.638<$ Ttabel 2.06 menunjukkan bahwa variabel ukuran perusahaan tidak berpengaruh signifikan terhadap volatilitas harga saham pada perusahaan manufaktur yang terdaftar di Bursa Efek Indonesia periode 2012-2016, sehingga hipotesis ketiga ditolak. Hasil penelitian ini sesuai dengan Khurniaji(2013) yang mendapati hasil bahwa ukuran perusahaan berpengaruh negatif atau tidak berpengaruh secara signifikan

Ukuran perusahaan adalah suatu skala atau nilai dimana perusahaan dapat diklasifikasikan besar kecilnya berdasarkan total aktiva, log size, nilai saham dan lain sebagainya. Beberapa proksi yang biasanya digunakan untuk mewakili ukuran perusahaan yaiut total aset, jumlah penjualan, dan kapitalisasi pasar. Jumlah aset perusahaan yang besar belum tentu memiliki dampak positif bagi volatilitas harga saham perusahaan. Hal ini dapat dilihat dari hasil penelitian yang dilakukan.

\section{Pengujian Hipotesis Keempat}

Ha4 : Volume Perdagangan berpengaruh signifikan terhadap volatilitas harga saham

Berdasarkan pada tabel 4.7 hasil uji regresi linier berganda diperoleh nilai signifikansi $(0.333>0.05)$ Sedangkan nilai Thitung0.988 < Ttabel 2.06 menunjukkan bahwa variabel volume perdagangan tidak berpengaruh signifikan terhadap volatilitas harga saham pada perusahaan manufaktur yang terdaftar di Bursa Efek Indonesia periode 2012-2016, sehingga hipotesis keempat

ditolak. Hasil penelitian ini tidak sesuai dengan hasil penelitian yang dilakukan oleh Hugida(2011) dan

Rahmawati(2017) yang menyatakan bahwa volume perdagangan memiliki pengaruh positif dan signifikan. Perbedaan hasil penelitian ini bisa disebabkan oleh perbedaan objek dan sampel yang diteliti.

Volume perdagangan saham adalah banyaknya lembaran saham suatu emiten yang diperjualbelikan di pasar modal setiap hari dengan tingkat harga yang disepakati oleh pihak penjual dan pembeli saham. Volume perdagangan yang tinggi belum tentu mempengaruhi volatiitas harga saham hal ini dapat disebabkan jumlah permintaan saham yang terus menerus meninggi tanpa ada panurunan, hal ini dapat terjadi pada saat perusahaan baru listing di bursa efek sehingga penawaran akan saham akan terus menerus meningkat.

\section{Pengujian Hipotesis Kelima}

Ha5 :Nilai Tukar berpengaruh signifikan terhadap volatilitas harga saham

Berdasarkan pada tabel 4.7 hasil uji regresi linier berganda diperoleh nilai signifikansi $(0.664>0.05)$ Sedangkan nilai Thitung $0.440<$ Ttabel 2.06 menunjukkan bahwa variabel nilai tukar tidak berpengaruh signifikan terhadap volatilitas harga saham pada perusahaan manufaktur yang terdaftar di Bursa Efek Indonesia periode 2012-2016, sehingga hipotesis kelima ditolak. Hal ini tidak sejalan dengan hasil penelitian yang dilakukan

oleh Hugida (2011), dalam penelitiannya menyatakan bahwa nilai tukar berpengaruh positif dan signifikan terhadap volatilitas harga saham. Perbedaan hasil ini dapat disebabkan 
perbedaan periode waktu yang diambil sebagai sampel.

Nilai tukar atau kurs adalah harga mata uang suatu negara terhadap negara lain atau mata uang suatu negara dinyatakan dalam mata

uang negara lain. Suatu kenaikan dalam kurs disebut depresiasi atau penurunan nilai mata

uang dalam negeri terhadap mata uang asing. Perubahan nilai mata uang secara tidak langsung dapat mempengaruhi harga saham yang diejualbelikan, perubahan ini sering dijadikan indikasi sebagai sinyal bagi investor untuk menjual atau membeli saham, meskipun begitu perubahan mata uang belum tentu menarik perhatian investor untuk membeli atau menjual saham, hal ini disebabkan sifat kewaspadaan investor dalam bertindak.

\section{Pengujian Hipotesis Keenam}

Ha6 : Inflasi berpengaruh signifikan terhadap volatilitas harga saham.

Berdasarkan pada tabel 4.7 hasil uji regresi linier berganda diperoleh nilai signifikansi $(0.883>0.05)$ Sedangkan nilai Thitung0.148 < Ttabel 2.06 menunjukkan bahwa variabel Inflasi tidak berpengaruh signifikan terhadap volatilitas harga saham pada perusahaan manufaktur yang terdaftar di Bursa Efek Indonesia periode 2012-2016, sehingga hipotesis keenam ditolak. Hasil ini sesuai dengan hasil penelitian yang dilakukan oleh Rahmawati(2017) yang menyatakan bahwa inflasi berpengaruh negatif atau tidak signifikan terhadap volatilitas harga saham. Tetapi hasil ini berbeda dengan yang dilakukan oleh Hugida(2011) yang mendapati hasil bahwa inflasi berpengarug positif dan signifikan terhadap volatilitas harga saham.

Inflasi adalah suatu proses meningkatnya harga-harga secara umum dan terus menerus, dengan kata lain inflasi juga merupakan proses menurunnya nilai mata uang secara terus- menerus. Hal ini berarti investor yang ingin berinvestasi dalam saham perusahaan manufaktur tidak perlu memperhatikan tingkat inflasi selama inflasi tersebut masih dibawah $10 \%$. Investor beranggapan bahwa berinvestasi pada perusahaan manufaktur akan tetap menghasilkan laba karena saham yang dimiliki oleh perusahaan manufaktur adalah saham dengan likuiditas yang tinggi.

\section{Pengujian Hipotesis Ketujuh}

Ha7 :Tingkat Suku Bunga berpengaruh signifikan terhadap volatilitas harga saham

Berdasarkan pada tabel 4.7 hasil uji regresi linier berganda diperoleh nilai signifikansi $(0.305>0.05)$ Sedangkan nilai Thitung1.048 < Ttabel 2.06 menunjukkan bahwa variabel Tingkat Suku Bunga tidak berpengaruh signifikan terhadap volatilitas harga saham pada perusahaan manufaktur yang terdaftar di Bursa Efek Indonesia periode 2012-2016, sehingga hipotesis ketujuh ditolak. Hasil penelitian ini sesuai dengan penelitian yang dilakukan oleh Hugida(2011), dalam penelitian mendapati hasil bahwa tingkat suku bunga berpengaruh negatif dan tidak signifikan.

Tingkat suku bunga atau interest rate merupakan rasio pengembalian sejumlah investasi sebagai bentuk imbalan yang diberikan kepada investor. Besarnya tingkat suku bunga bervariatif sesuai dengan kemampuan debitur dalam memberikan tingkat pengembalian kepada kreditur. Tingkat suku bunga tersebut dapat menjadi salah satu pedoman investor dalam pengambilan keputusan investasi pada pasar modal. Sebagai wahana alternatif investasi, pasar modal menawarkan suatu tingkat pengembalian (return) pada tingkat resiko tertentu. Dengan naiknya atau turunnya tingkat suku bunga

berdasakan penelitian investor di perusahaan manufkatur tidak perlu khawatir dikarenakan perubahan tingkat suku bunga. 


\section{Pengujian Hipotesis Kedelapan}

Ha8 : Devidend Payout Ratio,

Devidend Yield, Ukuran Perusahaan,

Volume Perdagangan, Nilai Tukar, Inflasi, Tingkat Suku Bunga secara simultan berpengaruh terhadap Volatilitas Harga Saham.

Secara simultan penelitian ini menunjukkan bahwa variabel penelitian yakni Devidend Payout Ratio, Devidend Yield, Ukuran Perusahaan, Volume Perdagangan, Nilai Tukar, Inflasi, Tingkat Suku Bunga

berpengaruh terhadap volatilitas harga saham. Hal ini dikarenakan hasil pengujian yang telah dilakukan menunjukkan bahwa nilai signifikan sebesar $0.032<0.050$ dan Fhitung 2.713 dan nilai Fhitung2.713> 2.42 Ftabel. . Maka dapat disimpulkan bahwa secara simultan variabel independen penelitian berpengaruh terhadap perubahan laba.

\section{Kesimpulan}

1. Devidend Payout Ratio berpengaruh signifikan terhadap Volatilitas Harga Saham pada Perusahaan Manufaktur yang Tercatat pada Bursa Efek Indonesia Tahun 2012-2016.

2. Devidend Yield tidak berpengaruh signifikan terhadap Volatilitas Harga Saham pada Perusahaan Manufaktur yang Tercatat pada Bursa Efek Indonesia Tahun 2012-2016.

3. Ukuran Perusahaan tidak berpengaruh signifikan terhadap Volatilitas Harga Saham pada Perusahaan Manufaktur yang Tercatat pada Bursa Efek Indonesia Tahun 2012-2016.

4. Volume Perdagangan tidak berpengaruh signifikan terhadap Volatilitas Harga Saham pada Perusahaan Manufaktur yang Tercatat pada Bursa Efek Indonesia

Tahun 2012-2016.

5. Nilai tukar berpengaruh tidak signifikan terhadap Volatilitas Harga Saham pada Perusahaan Manufaktur yang Tercatat pada Bursa Efek Indonesia Tahun 20122016.

6. Inflasi berpengaruh tidak signifikan terhadap Volatilitas Harga Saham pada Perusahaan Manufaktur yang Tercatat pada Bursa Efek Indonesia Tahun 20122016.

7. Tingkat Suku Bunga tidak berpengaruh signifikan terhadap Volatilitas Harga Saham pada Perusahaan Manufaktur yang Tercatat pada Bursa Efek Indonesia Tahun 2012-2016.

8. Devidend Payout Ratio, Devidend Yield,

Nilai Tukar, Inflasi, Ukuran Perusahaan, Tingkat Suku Bunga, Volume Perdagangan berpengaruh simultan dan signifikan terhadap Volatilitas Harga Saham pada Perusahaan Manufaktur yang Tercatat pada Bursa Efek Indonesia Tahun 2012-2016.

9. Nilai (Adjusted $R$ Square) sebesar 0.279 atau $27.9 \%$. Hal ini berarti $27.9 \%$ dari volatilitas harga saham dapat dijelaskan atau dipengaruhi oleh variabel Devidend Payout Ratio, Devidend Yield, Ukuran Perusahaan, Volume Perdagangan, Nilai Tukar, Inflasi, dan Tingkat Suku Bunga. Sedangkan sisanya sebesar 0.721 atau $72.1 \%$ dijelaskan atau dipengaruhi oleh variabel atau faktor internal dan eksternal lainnya

\section{Saran}

Berdasarkan kesimpulan dan keterbatasan pada penelitian ini, maka dapat disampaikan beberapa saran sebagai berikut, Bagi calon investor yang ingin berinvestasi pada saham perlu memperhatikan faktor-faktor yang mempengaruhi volatilitas harga saham yaitu devidend payout ratiokarna faktor tersebut memiliki pengaruh yang signifikan terhadap

volatilitas harga saham pada perusahaan manufaktur. Bagi peneliti selanjutnya penelitian dengan topik sejenis perlu dilakukan, penambahan variabel dengan 
variabel seperti frekuensi perdagangan, order imbalance, dan dapat melakukan penelitian dengan objek sampel yang berbeda seperti perusahaan yang terdaftar di LQ45 atau perusahaan keuangan. Penelitian selanjutnya sebaiknya memperpanjang periode penelitian. Mengingat investor lebih melihat prediksi

jangka panjang dibandingkan prediksi jangka waktu yang relatif pendek

\section{DAFTAR PUSTAKA}

Anastassia \& Frisrka Firnanti. 2014. FaktorFaktor yang Mempengaruhi Volatilitas Harga Saham pada Perusahaan Publik non Keuangan, Jumal Bisnis dan Akutansi, Vol.16 No. 2, Desember, Hal: 95-102.

Brigham, et al. 1999. Financial management Theory and Pactice. Thirteenth Edition. Michael C. Enrhard. Singapore. hal 333,557.

Buana Gresna dan Mulyo Haryanto. 2016. Pengaruh Risiko Pasar, Nilai Tukar, Suku Bunga, dan Volume Perdagangan terhadap Return Saham. Diponegoro Joumal Of Management, Vol. 5, No. 2, Hal: 1-14

Core Course. 2011. Fundamental of Investment. University of Calicut.

Ghozali, Imam. 2011. Analisis Multivariate dengan Program SPSS . Semarang: Badan Penerbit Universitas Diponegoro

Ghozali, Imam. 2016. Analisis Multivariate dengan Program SPSS. Semarang: Badan Penerbit Universitas Diponegoro

Hashemijo. 2012. The Impact of Devidend Policy on Share Price Volatility in the
Malaysian Stock Market. Vol 4 No 1pp 111-129

Hugida Lydinanita \& Syofian Syuhada. 2011. Analisis Faktor-Faktor yang Mempengaruhi Volatilitas Harga Saham. Hal: 1-27

Kenyoru et all. 2013. Devidend Policy and Share Price Volatility in Kenya. Vol 4 No 6.

Khurniaji Andreas Widhi \& Surya Raharja,. 2013. Hubungan Kebijakan Deviden Payout Ratio dan Devidend Yield terhadap Volatilitas Harga Saham di Perusahaan yang Terdaftar di BEI. Diponegoro Journal O Management, Vol. 2, No. 3, Hal: 1-10.

Mardiyanto, Handono.2009. Intisari Manajemen Keuangan. Jakarta :Grasindo Martalena \& Maya Malinda. 2011. Pengantar Pasar Modal. Yogyakarta: Andi. Martono \& Agus Harjito. 2008. Manajemen Keuangan. Yogyakarta: Ekonosia.

Nor Hadi. 2013. Pasar Modal Acuan Teoritis dan Praktis Investasi di Instrumen Keuangan Pasar Modal. Yokyakarta: Graha Ilmu

Priyanto, Duwi. 2009. SPSS Untuk Analisis Korelasi, Regresi, dan Multivarited. Yogyakarta: Gava Media

Rahmawati Irma. 2017. Pengaruh Volume Perdagangan, Devidend Payout Ratio, Ilflasi terhadap Volatilitas Harga Saham pada Perusahaan yang Terdaftar dalam Indeks LQ45 tahun 2011-2015, Jurnal Pendidikan dan Ekonomi, Vol. 6, Nomor 1, Hal: 38-45.

Suliyanto. 2011. Ekonometrika Terapan. Teori dan Aplikasi. Jakarta: Erlangga 
Supriyanti, Neni. 2008. Analisis Pengaruh Inflasi dan Suku Bunga BI terhadap Kinerja Keuangan. Universitas Gunadarma.

Supriaynto, Johanes.2000.Statistik Teori dan Aplikasi. Jakarta: Erlangga

Sujarweni, Wiratna. 2015. Metodologi Penelitian Bisnis dan Ekonomi. Yogyakarta: Pustaka Baru Press.

Sugiyono. 2010. Metode Penelitian Kuantitatif, Kualitatif, . Bandung: Alvabeta

Sugiyono. 2016. Metode Penelitian Kuantitatif, Kualitatif, dan $R \& D$. Bandung: Alvabeta

Waluyo Wawan. 2016. Analisis Determinasi Volatilitas Harga Saham. Fakultas Ekonomi. Universitas Yogyakarta 